\title{
Joseph Nye's Soft Power Theory and Its Revelation Towards Ideological and Political Education
}

\author{
Li Lin ${ }^{1, *}$, Leng Hongtao ${ }^{1,2}$ \\ ${ }^{1}$ School of Marxism Studies, Dalian Ocean University, Dalian, China \\ ${ }^{2}$ Faculty of Humanities and Social Sciences, Dalian University of Technology, Dalian, China
}

Email address:

lilin@dlou.edu.cn (Li Lin), lenght@dlut.edu.cn (Leng Hongtao)

*Corresponding author

\section{To cite this article:}

Li Lin, Leng Hongtao. Joseph Nye's Soft Power Theory and Its Revelation Towards Ideological and Political Education. Humanities and Social Sciences. Vol. 5, No. 2, 2017, pp. 69-74. doi: 10.11648/j.hss.20170502.13

Received: January 14, 2017; Accepted: March 29, 2017; Published: April 6, 2017

\begin{abstract}
The theoretical starting point of Joseph Nye's soft power theory is the dissatisfaction towards the explanatory power of the international relationship pattern. He thinks that realism emphasize too much the hard power. However, today, culture, policy and sense of value become more and more important in the international relationship. In that case, all the countries should learn to use new power source to realize its goal. The new source of power is called "the soft power" by Joseph Nye. Ideological and political education not only has the Chinese characteristic but also significantly represents the soft power. Thus, enhance the education of mainstream culture and core value of socialism for the college students, guide them to set up the correct sense of value, develop the ideological and political education healthily and enhance the national soft power.
\end{abstract}

Keywords: Soft Power, Joseph Nye, Ideological and Political Education, Revelation

\section{Introduction}

Joseph Nye's "Soft Power" theory produces in 20th century 90 's, which is a response to whether the of decline of United States happens. Joseph Nye's "Soft Power" theory is both the product as the development of traditional international relationship theory continues and the consequence of requirement of the international policies of the United States. The starting point of Joseph Nye's "Soft Power" theory is the unsatisfactory towards the explanatory power with the realism pattern of international relationship. He thinks that realism emphasizes the hard power too much. However, nowadays, cultures, policy, sense of value become more and more important when tackling the international affairs. In that case, all the countries should learn new source of power to realize their purpose. The new power is named as the soft power by Joseph Nye. It still provides China with significant insight into the development of Ideological and Political Education.

\section{The Proposal of the Soft Power Concept}

In 1990, Joseph Nye pointed out in his published book "Is the US destined to lead the world? The change of the US power property", in the international politics, the success of one country probably stems from the fact that other countries set it as the example, or accept a new rule. The power which can guide the capabilities, culture, ideology and the social system of others can be called the soft power. [1] This is the original definition by Joseph Nye. In the same year, Joseph Nye published the article "The soft power", precisely defined the soft power, he pointed that the soft power is the ability of the cultural recognition and guide others to follow, and this powers stems from the attractiveness of the culture and sense of value of a nation.

Since the proposal of the soft power, the viewpoint of Joseph Nye has a process to change. He gradually develops and improves the soft power concept. In the latter papers published by Joseph Nye, "the hard power and the soft power" and "the soft power- the success secret of international politics", he pointed out the US not only has the hard power, 
the military force and the economy, but also has the soft power, namely the culture and sense of value. "The soft power affects, attracts, and persuade others to believe and admit the rule, sense of value, life style and social system through the spiritual and morality requirements."[2] Joseph Nye thinks that, the soft power is the ability to affect the hobbies. The dictatorial countries use the force the let out the commands, the democratic countries use the attractiveness. Thus, the soft power is called the major method in the daily politics. The expected achievements of one country in the international politics lies the fact that other countries show respect to their sense of value, and expects to reach the standard and then would love to follow. The consequence to let others realize their dream is just to use the attractiveness. The soft power is not only the ability to persuade and guide, but also contains the attractive power. The attractive power can let others choose the default attitude when doing something. Thus the soft power is the power which can attractive others. The soft power can use different methods to help cooperation, use the same sense of value to produce the attraction.

Table 1. Action types and resource utilization of the hard power and the soft power.

\begin{tabular}{lll}
\hline & Hard power & Soft power \\
\hline Behavior & command & Setting the agenda \\
type & Stress & attract \\
coordinates & Induced & absorb \\
Most likely & force & Political Values \\
to use of & transaction & Institutional system \\
resources & Sanction & Cultures. \\
& bribery & Foreign Policies \\
\hline
\end{tabular}

The "soft power" theory, coined by Joseph Nye, is supplement and extension of traditional hard power ideology, and a return to classical realism, as well as a criticism about the fact that neorealism rely overwhelmingly on hard power. Joseph Nye proposes that "soft power is a kind of ability which can realize the goal through attraction instead of the violence or the temptation. The attractiveness arises from a country's culture, political ideals and foreign policies. When the policy is seen as legitimate in the eyes of others, the soft power is enhanced." [3] Therefore, the Soft Power theory is a supplement and improvement of international power theory, as well as an indispensable component of a country's comprehensive strength during globalization.

\section{The Main Resources of Soft Power}

The soft power of a country rests primarily on three resources: its culture (in places where it is attractive to others), its political values (when it lives up to them at home and abroad), and its foreign policies (when they are seen as legitimate and having moral authority).

\subsection{Cultures}

"Culture is the set of practices that create meaning for a society [3] and is the behavior pattern of disseminating knowledge and values" [4]. Joseph Nye distinguishes cultures into 3 levels which are universal cultures, ethnical cultures and other cultures owned only by people in certain social strata or some small organizations. If the universal value exists in the culture of a country whose policies are accepted by people in other countries, the possibility of achieving its goal will raise due to its attraction and trust, which is the effect of the cultural soft power. However, generally the possibilities are low for narrow values and populism culture to create the soft power. The culture here refers to high culture such as literature, technology and education; and popular culture, which focuses on mass entertainment such as music and movie.

In Joseph Nye's opinion, the utility of power resources rests on the environment, and soft power could rest on popular culture. However, the actions of soft power and the cultural resources that create soft power cannot be treated equally because, if so, we are confusing cultural resources with the action of bring out attraction. As for the quantitative criteria of soft power, Joseph Nye focuses on the export of movies and TV programs, the sales volume of music and books, the number of oversea students and the number of foreign tourists.

\subsection{Political Values}

Joseph Nye thinks that not only do values exist in the resources where other soft powers rest on, they themselves are also an important resource of soft power. He has pointed out in "Rethink on Soft Power" that the political value followed both domestically and internationally makes one of the resources of soft power. [5]

If the value is in accordance with both of the actions and the one they advocate, with other countries' recognition, the legality of the policies will be enhanced, which helps to achieve the goals of diplomatic policies. On the contrary, if the value differ from what they actually say and do or double standards are implemented, the soft power will be harmed.

Joseph pointed out in "Bound to Lead-The Changing Nature of America" that establishing a set of rules and systems, which are self-interested and can dominate international political affairs, is an important source of power. [6] Therefore, if a country wants to play a role in the world political agenda, it is necessary to establish and dominate the international rules, in which way it would be able to affect others' understanding and preference on its own national interests, in other words, obtain its soft power. To some extent, the ability of dominating the international organizations, the number of participated international organizations and the capability of making international rules are all reflections of systematic power.

\subsection{Foreign Policies}

The domestic and foreign policies are another resource that soft power rests on. The attraction or the soft power of a country is also generated by policies which are regarded as legalistic and allow others' interest. Joseph thinks that those diplomatic policies regarded as legalistic and share moral authorities are one of the soft power's resources. The hypocrisy, arrogance, indifference as well as domestic and foreign policies based on narrow national benefits will do 
harm to its soft power. The value that a country advocates in domestic and foreign policies, and international mechanism is able to influence other countries' preferences. The government action itself can also generate attraction as well as repulse to others. Therefore, whether there exists soft power in a country's domestic and foreign policies relies on the legality and morality of these policies.

The extent to which a country participates in multilateral mechanism, the level of foreign aid and external security have become a standard to measure the soft power of its domestic and foreign policies. The major indicator to measure whether soft power exists in domestic policies is the number of immigrants attracted. [7]

\section{Sources of Soft Power}

Joseph Nye proposes that soft power comes from resources and its utilization. Soft power plays a role well on the basis of resources. Whereas hard power grows out of a country's economic, technical and military might, soft power arises from the attractiveness of its culture, political ideas and policy. Each nation has diverse sources of soft power. In 1990, Joseph Nye writes in article «soft power» that culture, ideology and international policy, are the main factors of soft power. In the book «Hard Power and Soft Power» published in 2005, he points out that expectation initialization is correlated with implicit power resources, such as culture's attraction, political values and policy which are regarded as legitimate or has moral authority." [8]

\subsection{Cultural Radiation}

Culture has attraction and assimilation ability, which means that it exerts thought and values on others, such that they have the same perception. The assimilation feature is useful for a country's diplomatic goal realization. Culture has various styles and Joseph Nye summarize two classes, namely high culture (high-brow) and popular culture (low-brow).

High culture can unfold its beauty to people and will conquer its admirer emotionally. Meanwhile, it will show inventor's lofty sentiments and excellent creative abilities. The implicit power in high culture can bring encouragement and produce effective pervasion. A country with abundant high culture is a respectful and attractive nation, which has profound cultural background, and strong national spirit.

America's popular culture has a widespread influence in the world, such as NIKE, McDonald and Hollywood, which all have completely illustrated the power of popular culture to the world and the culture has continuously influenced people's lifestyle and hobby. Popular culture has strong penetrability and has been in all countries in the world. Joseph Nye points out that: "The political effect produced by popular culture is not entirely new.'[9] Meanwhile, popular culture has helped Unites States achieve important foreign policy goals. Continuous penetration of popular culture promotes America's culture and ideology. America cultural product has its specific values. The export of popular culture, such as
Hollywood, Jazz, exerts subtle influence on other country's popular values and psychology. If the importer supports and accepts the exported culture, then the exporter has the ability to reshape other's preference.

Joseph Nye thinks that America culture diversifies as well as integrates. Values is dominant, especially individualism and pragmatism. He points out that because English is universal in international economy, it spares a lot of energy for America to occupy considerably useful soft power resources.

\subsection{Political Values Inspiration}

A country is not truly strong unless it has powerful ideological system. The system depends on values' appeal, which is an import component of soft power.

Democracy and human rights values can become strongly attractive power. Joseph Nye regards that western democratic countries show democratic priorities and people believe democracy can bring free and equal life. Gradually, democracy becomes universal values. Western countries attract attention through transmitting democratic priorities such that it promotes the process of democracy.

Rules are a series of principles, regularizations and decisions made by a country. However, it is not once and for all. Only with continuous innovation, can it keep its leading position in international relationships. And then it can attract other countries to study, thus helping it seek greater interests in economics and politics. Currently, United States becomes dominant in the world pattern is due to continuous innovation is social mechanism design. Even though there exists ideology difference, China has a lot to learn and reference from United States.

\subsection{Foreign Policy's Influence}

A nation's policy at home and abroad is another element of soft power. Policy can be divided into short and long term effect depending on backgrounds' variation. Policy is realization of political values. People can feel political values' appeal through policy. Diplomatic policy, a way of realizing a country's cultural and political values, brings about a country's values recognition and international status through practice.

Joseph Nye points out that attractiveness of United States relies largely on the values expressed through the contents and styles of diplomatic policy. Many countries purse interests in foreign policy, however, soft power depends on the currency of attraction to mobilize cooperation rather than force or payoffs. To some degree, it depends on how a country frames its diplomatic objectives. If policy is based on broadly inclusive and far-sighted national interests, then it is more attractive than narrow and myopic perspective. Therefore, reasonable foreign policy can bring about reputation and credibility, and promote the realization of a country's strategic goal. The pursuit of interest is a country's instinct, and its foreign policy should benefit all. Reversely, if a country's foreign policy does damage to other countries, it does damage to itself. A country's foreign policy can attract attention and 
receive agreement through its friendly and positive value. Foreign policy can affect a nation's international status and popularity, as well as exert influence on its international and domestic political、economic environment.

\subsection{A country and Nation's Cohesion}

Culture is a nation's soul, and a nation's spirit represents a country's culture. The value goal represented by a nation's spirit is a cohesive force for a country. A country's cohesion can also be expressed through attraction and inspiration to other countries.

Cohesion is the ability to aggregate human and things. For a country, cohesion means aggregation and combination of all the people, to realize the same goals together. If a country has strong cohesion, it will win considerable trust and favor. Morgenthau mentions that a country's power will be affected by its national character because those people, who serve the country, make and execute policies in different periods, will have imprints of national character wisdom and moral characters. A nation's cohesion is a country's spiritual power. If a weak nation can unite together, they will be able to defeat strong enemies. But if a nation fight and diverge inside, it will cause perish. For example, at the beginning of World War II, Soviet Union unite together to defeat strong Fascism at the moment of life and death. It is an example of strong national cohesion.

\section{The Functions of Soft Power}

Joseph Nye regards culture, political values and foreign policy as the essential soft power resources. Culture, as a kind of superstructure, has very important influence on a nation. Political values expresses a country's political ideals and earns international recognition and legality. Foreign policy includes a country's advocated international ideals and concrete measures, thus becoming an import component of soft power. Political values is the core element, culture is the support, and foreign policy is the method. These elements are closely connected and interacted.

\subsection{Culture has Penetrating Effect on a Country's Influence}

Culture, as a kind of superstructure, can attract and absorb others; therefore, it plays an import role in a country's influence. Culture is the foundation of soft power, as well as a way of expressing soft power attraction and penetration.

Soft power changes other country's behavior to benefit a country through attraction, inspiration and assimilation. If a country's culture aims to attract other countries, the culture must be advanced, and keep up with time trends and social progress. America's popular culture swept the world is mainly due to the spirits conveyed by the culture besides its diversity. "America dominates movie, television and electronic communication through free ambition and equality trends. Information and popular culture have already increased worlds' attention and openness on American values."[10] Joseph Nye thinks American culture has worldwide inspiration and assimilation is due to its universal values and assimilation power. For example, during cold war, elegant culture contacts, academic and technology communication create soft power for America. Even popular sports can play an import role in communication of values and Elites' cultural contacts can produce attraction and soft power, finally contributing to America's policy goal achievement.

Strong cultural soft power is the reason why a nation can survive and succeed in international competition. Culture is invisible, but it always affects people's life. As some scholars point out that, "A country's soft power relies more on international culture's potential energy, which is the international culture and values trends" [11]. The democratic values promoted by the western countries and popular culture's propagation is an expansion of cultural attraction.

\subsection{Political Values has Identity on a Nation's Political Ideal}

The value propagated by a country is the influence on other countries' preference produced by its action at home and abroad, as well as its foreign policy. A country can attract or exclude others through model function.

Ideology and values have significant meaning on a nation because a nation can be strong with the influential ideological system. "Any countries in the history need to adapt their political needs and political ideology which serves their economic foundation and social system. Otherwise, state system will lose its legal principle of rules that can subvert a nation's political system."[12] A nation's political ideal is reflected in political values which has international recognition or international validity. Western countries carry out liberal democracy political ideal. Although it is defective, it represents some countries' pursue on freedom and democracy. The United States leads the world in politics, economy, religion etc. And much of that depends on its influence of political values.

\subsection{Foreign Policy Plays a Strategic Role in a Country's Specific Diplomatic Approaches}

Foreign policy includes the advocated world ideals and specific diplomatic approaches of a country. Joseph Nye points out that, Iraq war ran out of America's Soft Power. According to a reliable survey, the Iraq war has exerted influence on both countries. For America, it means the end of neoconservation. Therefore, America has changed a series of foreign policies after the war. China has won over a great many support and favor through its harmonious foreign policies, which also mitigate other countries' worries about the rise of China and help

China build a peaceful vfriendly and responsible image. In his view, "If foreign policy is based on comprehensive and long term interests of a country, it can attract attention much easier than narrow and short-sighted policy. Likewise, if a policy conveys important values shared by all countries, it will become more attractive." [13] This comment summarizes sufficiently about the influence and function of foreign policy 
on a country's soft power, as well as the conditions and approaches. Therefore, foreign policy, which can affect a country's international status as well as domestic politics and economy, is very important for an independent country.

\section{Soft Power Theory's Inspiration on College Students' Ideological and Political Education}

Nowadays, the status and role of soft power is emerging gradually onto the surface in the competition of comprehensive national strength. The invisible soft power, such as culture and values, tends to play an increasingly important role in the social development. With the rapid development of globalization and information, collision between culture and thought is intensified and social complexity is increasing, which will inevitably bring out new problems. In particular, the influx of western ideology, on the one hand, has helped broaden college students' horizons. On the other hand, it has affected their concept values to some degree. Under such social background, it requires us to strengthen the education of mainstream culture and socialist core values system for college students, ultimately helping them establish a correct outlook on life and values, and promoting the healthy development of ideological and political education.

First, we should further deepen college students' mainstream culture education. For one thing, taking the leading role, mainstream culture can largely reflect the country's mainstream ideology and then be widely accepted by the public. For another, it can exert huge influence on the national higher education's development. Currently, our mainstream culture features Chinese-characteristic socialism, which highlights the national spirit and ideology, and assimilates the Marxism culture, Chinese excellent traditional culture and the excellent culture across the world. Therefore, it will not only protect college students from invasion of some decadent western culture and values, but also improve their culture attainment and confidence through steering them towards right mainstream culture.

As the mainstream culture in contemporary China, the Chinese excellent traditional culture can deal with the impacts of globalization on college students' value concept, thus it can shed light on the cultivation of correct values for the students through carrying forward and inheriting the culture. The broad and profound Chinese culture involves achievements from philosophy of the social sciences, literature and art, as well as noble national spirit and sound morality, all of which are the most valuable resources for college students' mainstream culture education. When facing the shock wave of the foreign culture, the traditional excellent culture can take the essence and discard the dregs, since it possesses strong cohesion, charisma, powerful discrimination and inclusiveness. Therefore, it requires us to stress the role and status of excellent traditional culture to enhance college students' identification capabilities during mainstream culture education. In the group study session of the Political Bureau of the CPC Central Committee over various topics 13 times, comrade Xi Jinping stressed that:" Broad and profound Chinese excellent traditional culture is the foundation for us to maintain our foothold in the world culture collision. Owning a long history, Chinese culture has embodied the nation's deepest spiritual pursuit and has been representing the unique spirit of the national identity, unremittingly providing rich nourishment for Chinese development and growth." [14] Only equipped with sound moralities, could the contemporary college students set up correct life values. Moreover, excellent traditional Chinese culture focuses on the individualistic moral cultivation, which will not only cultivate college students' minds and improve moral level, but also will facilitate the mainstream culture education. Herein, it requires ideological and political educators "illustrate clearly the historical origin, development path and the basic trend of the excellent traditional Chinese culture; and explain plainly the unique creation, culture values and distinctive characteristics" [14], meanwhile, carrying forward the excellent traditional culture should be combined with pursuing national spirit and the spirit of the times to help college students receive mainstream culture education imperceptibly and further improve culture and values confidence.

Next, we should attach great importance to the socialist core values education of college students. In December 2013, the General Office of the CPC Central Committee issued <opinions about cultivating and acting on socialist core values $>$. It points out that: "cultivating and acting on socialist core values play realistically important roles in gathering positive energy for the realization of comparatively well-off society and the great rejuvenation of the nation". [15] The socialist core value provides guiding principle for college students' ideological and political education, and itself is the core and essence of the education.

Since their world outlook, outlook on life and values are still in the formation and development period, college students tend to get confused about the complicated social environment. Therefore, there exists a strong imperative to strengthen college students' socialist core values education, which will help promote the establishment of mainstream values heuristically. In 2013, during a conversation with representative youth elites from each fields, President Xi Jinping points out that "All the youth should combine the correct moral cognition, cultivation of consciousness of moral with active moral practices seamlessly to build and act consciously on the socialist core values and take the lead in advocating the good social convention. Everyone needs to strengthen the ideological and moral cultivation, spread patriotism, collectivism and socialism, actively promote social morality, occupation morality and family virtue. Educators should employ the Chinese dream to lay a solid foundation for the youngsters' ideology and help them foster correct world outlook, views on life and values, so that they love our motherland forever, love our great people forever, love our great Chinese nation unceasingly, and follow the party's lead resolutely" [16]. The socialist core values are the lead for the 
great rejuvenation of the Chinese nation, and the powerful spiritual force for us to realize the dream. Through socialist core values education, our aim is to enable the college students to combine the pursuit of personal goals with national development closely, thus finally realizing their own values in the great practice of building socialism.

In a nutshell, it is the motivation and strategic goal of the college students' ideological and political education to reinforce mainstream culture and socialist core values education. Meanwhile, as the soul and key to help students establish a correct outlook on life and values, it will retrospectively play a positive role in ideological and political education.

\section{Conclusion}

The soft power concept was coined by Joseph Nye. He proposes that soft power is a country's ability to achieve its goal through attraction and persuasion. It forces other countries to shape their preferences and benefits to fit this country. Soft power depends on attraction and persuasion instead of force and inducement, which is different from hard power based on economic and military power. This kind of attraction is derived from a nation's culture, values and foreign policy. When we are facing a current economic globalization and political multi-polarization world's development trends, soft power theory brings hints for college students' ideological and political education.

\section{Acknowledgement}

The paper subsidized by National Social Science Fund of China: Study from a comparative view to improve the soft power and the international influence of Chinese culture. 16CKS023; Sponsored by Liaoning Province Social Science Planning Fund: Study to improve the soft power of Liaoning's culture. L15cks003.

\section{References}

[1] Joseph S. Nye write, and He xiaodong, Gai yuyun translate. "Bound to Lead: The Changing Nature of American Power," Beijing: Yi Wen Publishing Military, 1992, pp. 25.
[2] Zhang Meng. The concept of soft power: propose, Development and criticism, vol. 7. Oxford: Field of vision, 2008, pp. 273.

[3] Hans. Morgenthau write, Kenneth. Thompson, David Clinton revise. The Politics between Countries: the Power Conflict and Peace. Beijing: Renmin Publishing House, 2005, pp. 74.

[4] Joseph S. Nye write, and Wang Jimei translate. The Future of power. Beijing: Published by Citic, 2012.

[5] Joseph S. Nye. Think Again: Soft Power. Foreign Policy. February 23, 2006.pp. 90.

[6] Joseph S. Nye write, and He xiaodong, Gai yuyun translate. "Bound to Lead: The Changing Nature of American Power," Beijing: Yi Wen Publishing Military, 1992, pp. 26.

[7] Yang Lingshu, Liu Dongchang. "The Introduction of national soft power," Beijing: China Financial Publishing House, 2012.

[8] Joseph S. Nye write, and Men Honghua translate. Hard power and soft power. Beijing: Beijing university Publishing House, 2005. pp. 7.

[9] Liu Yang. "soft power" Research Summary. Academic Exchange, vol.12.2009. pp. 157.

[10] Hong Xiaonan, Guo Lili. Study on the dialectical relationship between the development of national hard power and soft power. Journal of Cultural Studies. vol. 6. 2010. pp. 15.

[11] Wang Huning. Culture as a national power: soft power. Fudan Journal (Social Sciences Edition), vol. 3. 1993. pp. 91-95.

[12] Liu Wenfang. The political function of cultural products and the government behavior in the development of cultural industry. Contemporary Economics. vol. 17. 2012. pp. 34.

[13] Han Bo, Jiang Qingying. Soft Power: Chinese Perspective. Beijing: Renmin Publishing House, 2009.pp. 2.

[14] "To cultivate and carry forward the socialist core values isthe soul of the condensate gas gathering strong base solid foundation engineering. The Future of power -- Xi Jinping Political Bureau of the CPC Central Committee the thirteenth collective study stressed," The people's daily, 2014-02-26(01).

[15] The General Office of the Communist Party of China issued "On cultivating and Practicing Socialist Core Values opinion," Xinhuanet, 2012-12-23.

[16] Xi Jinping. "On the outstanding young representatives of speech," The people's daily, 2013-05-05(02). 